Chronic inflammation is a common feature of endstage renal disease, which carries a heightened risk of atherosclerosis and other co-morbid conditions. Dialysis treatment per se can bring additional risk factors for inflammation, such as increased risk of local graft and fistula infections, impure dialysate or bio-incompatible membranes. Our study was designed to determine whether a hemodialysis session leads to an acute substantial alteration in the plasma levels of the proinflammatory cytokines interleukin (IL)-6, IL-1 $\beta$ and tumor necrosis factor (TNF)- $\alpha$, the Tlymphocyte activation factor soluble IL-2 receptor (SIL-2R), and an inflammation mediator and chemotactic granulocyte factor, IL-8, in end-stage renal disease patients receiving chronic intermittent HD. In this study, 21 (12 male/nine female) patients undergoing chronic hemodialysis were enrolled. The acute effect of a hemodialysis session on serum cytokine concentrations was assessed by comparison of pre-hemodialysis and post-hemodialysis determinations. Serum IL-1 $\beta$, sIL-2R, IL-6, IL-8 and TNF- $\alpha$ levels were determined with chemiluminescence enzyme immunometric assays.

A significant difference was not observed for IL-1ß, IL6 , TNF- $\alpha$, and sIL-2R concentrations in pre-hemodialysis and post-hemodialysis specimens $(p>0.05)$. Serum median (25th-75th percentiles) IL-8 concentration was 69.4 (34.9-110.3) $\mathrm{pg} / \mathrm{ml}$ before hemodialysis, and decreased to $31.5(18.0-78.8) \mathrm{pg} / \mathrm{ml}$ following hemodialysis ( $p: 0.006$ ). Clearance of $\mathrm{IL}-8$ increased by $0.47 \pm 0.08 \mathrm{pg} / \mathrm{ml}$ for each unit increase in pre-dialysis IL-8 $(p<0.001)$ and decreased by $5.63 \pm 2.59 \mathrm{pg} / \mathrm{ml}$ for each unit increase in predialysis urea mmol/1 $(p<0.05)$.

In conclusion, the results of our study demonstrate that a hemodialysis session markedly decreases IL-8 concentration, which is significantly affected by predialysis concentrations, indicating that removal of IL8 is a concentration gradient-dependent action, but does not change the serum levels of IL-1ß, sIL-2R, IL6 , and TNF- $\alpha$, underlining importance of the structural characteristics of the molecules.

Key words: Hemodialysis, Proinflammatory cytokines, Soluble interleukin-2 receptor, Interleukin-8, Clearance

\section{Acute effect of hemodialysis on serum levels of the proinflammatory cytokines}

\author{
Mehmet Tarakçıŏlu ${ }^{1, C A}$, Ayşe Binnur Erbağci ${ }^{1}$, \\ Celalettin Usalan ${ }^{2}$, Rukiye Deveci ${ }^{1}$ and \\ Ramazan Kocabaş ${ }^{1}$
}

${ }^{1}$ Department of Biochemistry and Clinical

Biochemistry and ${ }^{2}$ Department of Nephrology,

Gaziantep University, Medicine Faculty, 27310

Şehitkamil Gaziantep, Turkey

\author{
${ }^{\mathrm{CA}}$ Corresponding Author \\ Tel: +90 $3423606060 / 7135$ \\ Fax: + 903423601617 \\ E-mail: tarakcioglu@gantep.edu.tr
}

\section{Introduction}

Recent evidence points to chronic inflammation as a major contributor to morbidity and mortality in endstage renal disease (ESRD). ${ }^{1}$ It has been proposed that a chronic inflammatory state could account for the high risk of ischemic heart disease in patients with ESRD. ${ }^{2}$ Malnutrition and chronic systemic inflammatory response syndrome not only co-exist in uremia, but may also have a bi-directional cause and effect relationship. ${ }^{3}$ Also, anemia appears to be an important element linking elevated proinflammatory cytokine levels with poor patient outcomes. ${ }^{1}$
Although the uremic state itself may impair lymphocyte, granulocyte and monocyte/macrophage function, defects in immunity can occur as a direct consequence of therapy. ${ }^{4}$ About $35-65 \%$ of ESRD patients receiving hemodialysis (HD) show signs of inflammation, whereas the prevalence in pre-dialysis patients may be somewhat lower. ${ }^{1}$ Dialysis has been associated with acute changes in the complement activation, granulocyte markers, macrophage function, T-cell activation and the release of various proinflammatory cytokines. ${ }^{4-6}$ Actually, recent data suggest that levels of the proinflammatory cytokines in HD patients are eight-fold to 10-fold higher than in healthy controls. Several studies have linked high 
levels of proinflammatory cytokines with poor outcomes in renal patients. In contrast, high levels of cytokines associated with better $\mathrm{T}$ cell function, such as interleukin (IL)-2 and IL-12, were associated with a survival advantage for these patients. ${ }^{1,7}$

Activation of the proinflammatory system in HD patients may be due to three mechanisms. Susceptibility to local graft and fistula infections, inflammatory response induced by bioincompatible dialysis membranes and exposure to contaminated dialysate containing cytokine-inducing substances such as endotoxins. ${ }^{1,3,8-10}$ On the other hand, clearance or membrane adsorption of cytokines during hemodialysis may alter circulating cytokine levels. ${ }^{11,12}$

Our study was designed to determine whether a HD session leads to an acute substantial alteration in the plasma levels of cytokines in ESRD patients receiving chronic intermittent $\mathrm{HD}$. The proinflammatory cytokines IL- 6 , IL- $1 \beta$ and tumor necrosis factor (TNF)- $\alpha$, the T-lymphocyte activation factor soluble IL-2 receptor (sIL-2R), and an inflammation mediator and chemotactic granulocyte factor, IL-8, ${ }^{13-16}$ were determined in sera specimens before and after HD.

\section{Materials and methods}

\section{Patients}

This study was conducted in 2001. Informed consent was obtained from all subjects according to the Helsinki declaration as revised in 1996. Twenty-one patients (12 male/nine female) with chronic renal impairment undergoing hemodialysis were recruited. Mean age $( \pm S D)$ was $47.3 \pm 14.2$ years. Body mass index of the subjects was $20.0 \pm 2.4 \mathrm{~kg} / \mathrm{m}^{2}$. Patients received an average of $12 \mathrm{~h}$ hemodialysis three times a week on a non-reprocessed synthetic dialyzer using polysulfone membranes: Fresenius F-6, $40 \mu \mathrm{m}$ thick of $1.3 \mathrm{~m}^{2}$ surface area (F6 polysulfone UF 5.5; Fresenius St, Wendel GmbH, Frankfurt, Germany). Mean dialysis time was $3.7 \pm 4.8$ years. Patients received no other medication except phosphate binders, ferrous sulfate, essential amino acids and angiotensin-converting enzyme inhibitors. The etiology of the ESRDs was diabetes mellitus $(n=6)$, hypertensive malign nephrosclerosis $(n=4)$, urolithiasis $(n=4)$, polycystic kidney disease $(n=2)$, chronic glomerulonephritis $(n=5)$.

\section{Protocol and experimental study}

Pre-HD and post-HD venous blood samples were collected using standard venipuncture technique 20 min before and after HD, respectively, into plain tubes. Sera were separated immediately after centrifugation at $+4{ }^{\circ} \mathrm{C}, 2000 \mathrm{~g}$ for $10 \mathrm{~min}$ and stored at $-20^{\circ} \mathrm{C}$ for 1 month. Serum IL-1 $\beta$, sIL-2R, IL-6, IL-8 and TNF- $\alpha$ levels were determined with chemiluminescence enzyme immunometric assays on an Immulite Immunoassay Analyzer (Immulite DPC, Los Angeles, CA, USA). Analytical sensitivities of IL-1 $\beta$, sIL-2R, IL-6, IL-8, and TNF- $\alpha$ assays were $1.5 \mathrm{pg} / \mathrm{ml}$, $10 \mathrm{U} / \mathrm{ml}, 1.0 \mathrm{pg} / \mathrm{ml}, 2.0 \mathrm{pg} / \mathrm{ml}$ and $1.7 \mathrm{pg} / \mathrm{ml}$, and the lower reportable ranges were $5.0 \mathrm{pg} / \mathrm{ml}, 50 \mathrm{U} / \mathrm{ml}, 5.0$ $\mathrm{pg} / \mathrm{ml}, 5.0 \mathrm{pg} / \mathrm{ml}$ and $4.0 \mathrm{pg} / \mathrm{ml}$, respectively. Immulite cytokine controls were included in each analytical run. Intra-assay and inter-assay precision performances of the assays were determined on 10 replicates in a single run and in 20 different runs, respectively and yielded coefficients of variation within the $4.2-8.9 \%$ range.

Total protein, albumin and urea concentrations were determined on a Roche/Hitachi modular analytics system (Roche Diagnostics, Indianapolis, IN, USA) with Roche reagents according to the manufacturer's instructions.

\section{Statistical analyses}

Demographic data were expressed in terms of mean \pm SD. The selected laboratory parameters are presented as median (25th-75th percentiles). IL-1 $\beta$ was expressed as proportion of detectable ( $\geq 5.0 \mathrm{pg}$ / $\mathrm{ml}$ ) cases. Paired differences were evaluated with the paired samples $t$-test and the Wilcoxon signed-rank test when necessary. Significant predictors of the paired difference (pre-HD minus post-HD values) of IL-8 levels were evaluated with univariate linear regression analysis. Statistical significance of the variables was established at the level $p<0.05$. The SPSS 9.0 (SPSS Inc., Chicago, IL, USA) program was used for statistical analyses and illustrations.

\section{Results}

Serum levels of the cytokines in samples taken before and after HD were compared. IL- $1 \beta$ values in most cases were below the detection limit. Three cases with detectable IL- $1 \beta$ in pre-dialysis and four cases in post-dialysis revealed $p=0.407$ by Wilcoxon signedrank test. Significant differences were not observed for IL-6, and sIL-2R concentrations in pre-HD and post-HD specimens ( $p>0.05)$. Serum median (25th75th percentiles) IL-8 concentration was 69.4 (34.9110.3) $\mathrm{pg} / \mathrm{ml}$ before $\mathrm{HD}$, and decreased to 31.5 (18.0-78.8) $\mathrm{pg} / \mathrm{ml}$ following $\mathrm{HD}(p=0.006)$. A significant increase for TNF- $\alpha(p=0.011)$ was noticed during hemodialysis (Table 1 ).

Serum total protein and albumin concentrations were significantly elevated after HD, a well-known criteria for hemoconcentration. ${ }^{17}$ By determining the values of relatively big molecules, sIL-2R and TNF- $\alpha$ per gram of total protein, we aimed to exclude 
Table 1. Circulating cytokine levels in pre-hemodialysis and post-hemodialysis specimens

\begin{tabular}{lccc}
\hline & Before hemodialysis & After hemodialysis & $p$ \\
\hline Total protein $(\mathrm{g} / \mathrm{l})$ & $69.9(65.7-73.5)$ & $76.1(70.6-84.9)$ & 0.001 \\
Albumin $(\mathrm{g} / \mathrm{l})$ & $38.7(36.0-41.8)$ & $42.6(38.3-48.9)$ & 0.001 \\
Urea $(\mathrm{mmol} / \mathrm{l})$ & $26.1(20.1-28.7)$ & $10.8(9.13-12.5)$ & 0.000 \\
IL-1 $\beta(\mathrm{detectable} \%)$ & $n=3,14 \%$ & $n=4,19 \%$ & 0.407 \\
IL-6 $(\mathrm{pg} / \mathrm{ml})$ & $15.3(7.0-24.9)$ & $21.4(7.0-26.5)$ & 0.913 \\
IL-8 $(\mathrm{pg} / \mathrm{ml})$ & $69.4(34.9-110.3)$ & $31.5(18.0-78.8)$ & 0.006 \\
TNF- $\alpha(\mathrm{pg} / \mathrm{ml})$ & $23.1(20.1-30.3)$ & $26.2(24.4-32.2)$ & 0.011 \\
sIL-2R $(\mathrm{U} / \mathrm{ml})$ & $4292(2431-6975)$ & $4473(2191-8474)$ & 0.968 \\
TNF- $\alpha(\mathrm{pg} / \mathrm{ml}) /$ total protein $(\mathrm{g} / \mathrm{l})$ & $0.35(0.29-0.43)$ & $0.36(0.29-0.45)$ & $0.679^{*}$ \\
sIL-2R $(\mathrm{U} / \mathrm{ml}) /$ total protein $(\mathrm{g} / \mathrm{l})$ & $64.2(35.4-95.8)$ & $58.6(27.1-19.1)$ & $0.601^{*}$ \\
\hline
\end{tabular}

Data presented as presented as median (25th-75th percentiles)

* Significance after correction for hemoconcentration.

possible effects of the hemoconcentration effect (Table 1). After correction for hemoconcentration, the increase in TNF- $\alpha$ concentration disappeared, possibly indicating a hemoconcentration rather than an absolute change in total serum. The paired difference for sIL-2R remained insignificant after correction for hemoconcentration. Pre-HD and postHD IL-8 concentrations of the patients are illustrated in Fig. 1.

Results of univariate regression analysis paired difference (PD) (pre-HD minus post-HD values) of IL-8 levels as the dependent variable are presented in Table 2 . The model included pre-dialysis IL- 8 values representative of the concentration gradient (as the dialysis solution does not contain any IL-8 at the beginning of the session), pre-dialysis and PD urea representative of accumulation and clearance of freely diffusible molecules, and pre-dialysis and PD of total protein concentrations representative of hemoconcentration. Only pre-dialysis IL-8 and predialysis urea concentrations were significant predic-

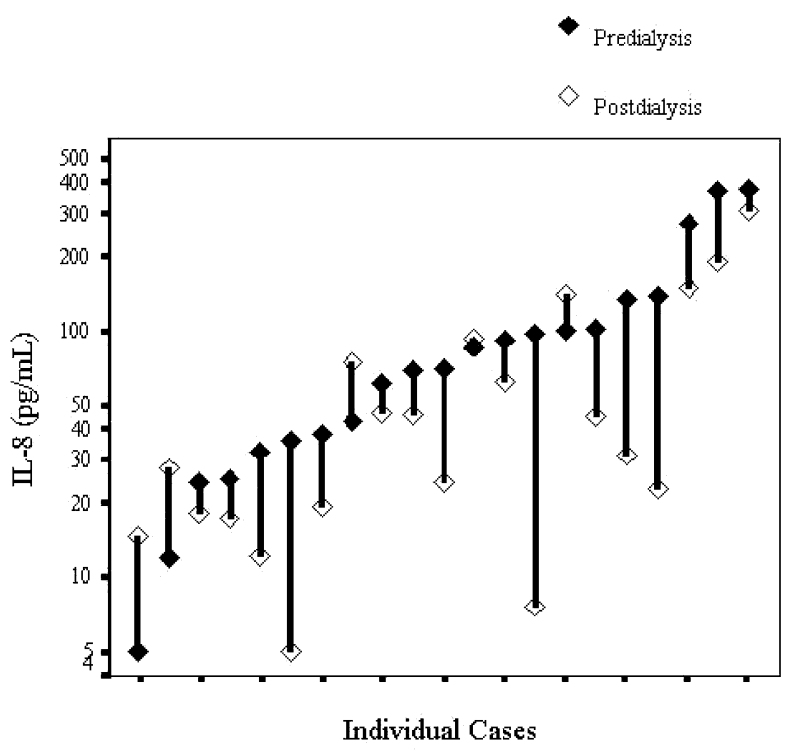

FIG. 1. Pre-hemodialysis and post-hemodialysis IL-8 concentrations of the patients arranged according to the prehemodialysis IL-8 values in ascending order on a semilogarithmic scale. tors of the PD IL-8. The relation with the PD of urea did not reach the significance level $(p=0.091)$. The $\mathrm{PD}$, or in other words removal of IL-8, increased by $0.47 \pm 0.08 \mathrm{pg} / \mathrm{ml}$ for each unit increase in predialysis IL-8 $(p<0.001)$ and decreased by $5.63 \pm$ $2.59 \mathrm{pg} / \mathrm{ml}$ for each $1.0 \mathrm{mmol} / \mathrm{l}$ increase in predialysis urea $(p<0.05)$. This model explains $58.7 \%$ of the variation in PD IL-8 $(p<0.005)$.

\section{Discussion}

The results of our study demonstrate that the serum concentrations of IL- 8 are decreased during HD but IL-1 $\beta$, sIL-2R, IL- 6 , and TNF- $\alpha$ remained unchanged over the course of measurement. Several studies reported unchanged serum IL-6, $, 11,18$ IL-1, 9,19 and TNF- $\alpha^{18}$ during HD concurrent with increased clearance or membrane adsorption of these cytokines. ${ }^{7,11}$ The reasons for this phenomenon probably depend on cytokine kinetics. The half-lives of IL-6 (3-7 min), and TNF- $\alpha(5-10 \mathrm{~min})$ are known to be rather short. Since plasma cytokines are rapidly bound to cell surface receptors, this implies that stable plasma concentrations are achieved by a continuously high production rate. As a consequence, the entire amount of cytokines potentially eliminated via hemodialysis is probably considerably lower when compared with the endogenous production. ${ }^{18}$ It is not unlikely that the serum concentrations of cytokines serve as target of feedback mechanisms, since their endocrine action has been shown, apart from paracrine actions. ${ }^{20,21}$ It must also be taken into account that adsorption of cytokines occurs mainly in the first minutes of HD and may not reflect a substantial amount of cytokine removal, ${ }^{18}$ and HD membranes may increase cytokine production by activating mononuclear cells. ${ }^{9,10,12}$ Magnitude and impact of biological variation of cytokines merit consideration for interpretation of the results of this study. Gonzales et al. assessed within-subject coefficients of variation (CVi) for cytokines by measurements at monthly intervals over a period of six consecutive months in healthy 
Table 2. Univariate linear regression analysis, paired difference (PD) (pre-hemodialysis minus post-hemodialysis values) of IL8 levels as the dependent variable

\begin{tabular}{lrrr}
\hline Covariate & B & \multicolumn{2}{c}{$95 \%$ confidence interval } \\
\cline { 3 - 4 } & & Lower bound & Upper bound \\
\hline Corrected model & - & & 0.002 \\
Intercept & -41.81 & -309.0 & 0.743 \\
Pre-dialysis IL-8 (pg/ml) & 0.47 & 0.29 & 0.65 \\
Pre-dialysis total protein (g/l) & 1.38 & -2.30 & 5.05 \\
PD total protein (g/l) & -1.95 & -4.70 & 0.79 \\
Pre-dialysis urea (mmol/l) & -5.63 & -11.16 & -0.10 \\
PD urea (mmol/l) & 4.50 & -0.81 & 9.80 \\
\hline
\end{tabular}

individuals. The within-subject variation is the average variation of results around the homeostatic mean of the individual. The CVi for IL-1 $\beta$, IL-8, and TNF- $\alpha$ were $30 \%, 24 \%$, and $43 \%$, respectively. ${ }^{22} \mathrm{CVi}$ for IL-6 was $30.5 \%$ in a short-term variability study. ${ }^{23}$ These data apparently indicate that the impact of biological variation of the cytokines is large on numerical results. So, it is possible to assume that any effect of hemodialysis on IL- $1 \beta$, sIL-2R, IL- 6 , and TNF- $\alpha$ may be masked by a biological variation of higher magnitude. However, the expected intra-individual variation of IL-8 $(\mathrm{Cvi}=24 \%)$ is much smaller than the CVi in our study (54.1\%; data not shown). Therefore, biological variation does not explain the observed difference between pre-dialysis and post-dialysis IL-8 concentrations.

Diverse elimination kinetics of the studied cytokines may be related to the differences in molecular structure. IL-6 (26.5 kDa), TNF- $\alpha$ (biologically active heterotrimeric form, $53 \mathrm{kDa}), \mathrm{IL}-1 \beta(17.5 \mathrm{kDa})$, sIL$2 \mathrm{R}$ (varies, $55-75 \mathrm{kDa}$ ) are relatively large molecules. IL-8 is a low molecular weight protein $(10 \mathrm{kDa})$ with a globular three-dimensional conformation, ${ }^{20,21}$ which possibly enables its diffusion through the dialysis membrane. In our study, the significant effect of pre-dialysis IL-8 levels on elimination of IL-8 observed may represent a concentration gradient, confirming this diffusion effect. Alternative or additional possible mechanisms of the observed decrease may be altered IL-8 production or stability, membrane adsorption of IL-8, or IL-8 producing cells during hemodialysis. It is now known that IL-8 production by various normal and pathological human cells can be either constitutive or can be induced by various stimuli, such as lipopolysaccharide, leukotrienes, IL-1, TNF- $\alpha$. Several stress factors such as hypoxia, acidosis, and nitric oxide (NO) significantly influence expression of IL-8 in tumorogenic human cells. ${ }^{14,20}$ Xie suggested that NO serves as an intracellular second messenger to regulate IL-8 gene expression, increasing IL-8 protein secretion and promoter activity. The rate of IL- 8 gene transcription was correlated with the level of IL-8 expression, suggesting that a constitutive level of IL-8 gene transcription was a major contributing factor in differential IL-8 expression. ${ }^{14}$ Therefore, decreased NO may be a contributing factor to decreased serum IL-8. ${ }^{24}$ The negative correlation of pre-dialysis urea levels with the PD of IL-8, however, is an unexpected finding and may simply result from a competition between freely diffusible molecules or somewhat lower pre-dialysis IL-8 levels in patients with higher pre-dialysis urea concentrations.

Heering et al. have demonstrated removal of IL-8 from the circulation by continuous hemofiltration but a reduction of plasma IL-8 levels is contradictory. ${ }^{25,26}$ Differences in the flow rates, amount of fluids and nature of membranes as well as the differences in the pathophysiology of the diseases (as they investigated critically ill patients) in our study and the aforementioned studies may have implications on the observed differences.

This study has some methodological limitations that might contribute to the fact that we did not find a significant difference for IL-1 $\beta$. The majority of the pre-HD and post-HD specimens had lower serum levels than the detection limit of the assay, which raises the possibility that phase differences might be present below the detection limit. Another potential limitation was the small number of the study group. A larger study population and a longitudinal study design, including more sessions, are needed to elucidate whether these alterations are consistent.

In conclusion, the results of our study demonstrate that a HD session markedly decreases IL-8 concentration, which is significantly affected by pre-dialysis concentrations, indicating that removal of IL-8 is a concentration gradient-dependent action. But a HD session does not change serum levels of IL-1 $\beta$, sIL$2 \mathrm{R}$, IL- 6 , and TNF- $\alpha$, underlining importance of the structural characteristics of the molecules.

\section{References}

1. Stenvinkel $P$. The role of inflammation in the anaemia of end-stage renal disease. Nephrol Dial Transplant 2001; 16: 36-40.

2. Bolton CH, Downs LG, Victory JGG, et al. Endothelial dysfunction in chronic renal failure: roles of lipoprotein oxidation and pro-inflammatory cytokines. Nephrol Dial Transplant 2001; 16: 1188-1197.

3. Schiffl H, Lang SM, Stratakis D, Fischer R. Effects of ultrapure dialysis fluid on nutritional status and inflammatory parameters. Nephrol Dial Transplant 2001; 16: 1863-1869. 
4. Zamauskaite A, Perez-Cruz I, Yaqoob MM, Madrigal JA, Cohen SBA Effect of renal dialysis therapy modality on $\mathrm{T}$ cell cytokine production. Nephrol Dial Transplant 1999; 14: 49-55.

5. Sester U, Sester M, Hauk M, Kaul H, Köhler H, Girndt M. T-cell activation follows Th1 rather than Th2 pattern in haemodialysis patients. Nephrol Dial Transplant 2001; 15: 1217-1223.

6. Capelli G, DiFelice A, Perrone S, et al. Which level of cytokine production is critical in haemodialysis? Nephrol Dial Transplant 1998; 13: $55-60$.

7. Kimmel PL, Phillips TM, Simmens SJ, et al. Immunologic function and survival in hemodialysis patients. Kidney Int 1998; 54: 236-244.

8. Yamasaki H, Nishi H, Nagake Y, Mino Y, Makino H. Changes in CD1 expression on monocytes and changes in serum soluble CD14 level during hemodialysis. Clin Exp Nephrol 2000; 4: 58-62.

9. Girndt M, Heisel $\mathrm{O}$, Köhler $\mathrm{H}$. Influence of dialysis with polyamide vs haemophan haemodialysers on monokines and complement activation during a 4-month long-term study. Nephrol Dial Transplant 1999; 14 $676-682$.

10. Gu Y, Ding F, Qin H, Zhao H, Lin S. Synergetic effect of dialyzer membrane and lipopolysaccharide on peripheral blood mononuclea cell cytokine production in uremic patients. Chin Med J 2000; 113: $315-$ 319.

11. Fujimori A, Naito H, Miyazaki T. Adsorption of complement, cytokines, and proteins by different dialysis membrane materials: evaluation by a confocal laser scanning flourescence microscopy. Artif Organs 1998; 22 $1014-1017$.

12. Lonnemann G, Koch KM, Shaldon S, Dinarello CA. Studies on the ability of hemodialysis membranes to induce, bind and clear human interleukin-1. J Lab Clin Med 1998; 112: 76-86.

13. Fischer K, Hamza A, Eisman R, Amoury M, Heynemann H, Fornora P. Differential diagnostic use of interleukin patterns in patients being monitored after transplantation. Clin Chim Acta 2001; 310: 71-80.

14. Xie K. Interleukin-8 and human cancer biology. Cytokine Growth Factor Rev 2001; 12: 375-391.

15. Hoffmann JN, Hartl WH, Faist E, Jochum M, Inthorn D. Tumor necrosis factor measurement and use of different anticoagulants: possible interference in plasma samples and supernatants from endotoxinstimulated monocytes. Inflamm Res 1997; 46: 342-347.
16. Aukrust $\mathrm{P}$, Berge RK, Ueland $\mathrm{T}$, et al . Interaction between chemokines and oxidative stress: possible role in acute coronary syndromes. $J \mathrm{Am}$ Coll Cardiol 2001; 37: 485-491

17. Tarakçioğlu $\mathrm{M}$, Erbağ $\mathrm{C1} \mathrm{AB}$, Çekmen $\mathrm{M}$, et al. Acute effect of hemodialysis on serum markers of myocardial damage. Int J Clin Pract 2002; 56: 328-332.

18. Sander A, Armbruster W, Sander B, Daul AE, Lange R, Peters J. Hemofiltration increases IL- 6 clearance in early systemic inflammatory response syndrome but does not alter IL- 6 and TNF $\alpha$ plasma concentrations. Intensive Care Med 1997; 23: 878-884.

19. Herbelin A, Nguyen AT, Zingraff J, Urena P, Descamps-Latscha B. Influence of uremia and hemodialysis on circulating interleukin-1 and tumor necrosis factor alpha. Kidney Int 1990; 37: 116-125.

20. Massey HD, McPherson RA. Cytokines and adhesion molecules. In Henry JB, ed. Clinical Diagnosis and Management by Laboratory Methods, Philadelphia: W.B. Saunders Co, 2001: 541-616.

21. Santos-Rosa M, Bienvenu J, Whitcher J. Cytokines. In: Burtis CA Ashwood E, eds. Tietz Textbook of Clinical Chemistry, Philadelphia: W.B. Saunders Co, 1999: 914-926.

22. Gonzalez C Cava F Ayllón A et al. Biological variation of interleukin$1 \beta$, interleukin- 8 , and tumor necrosis factor- $\alpha$ in serum of healthy individuals. Clin Chem Lab Med 2001; 39: 836-841.

23. Duguē B, Leppänen E. Short-term variability in the concentration of serum interleukin-6 and its soluble receptor in subjectively healthy persons. Clin Chem Lab Med 1998; 36: 323-325.

24. Hon WM, Lee JC, Lee KH. Effect of hemodialysis on plasma nitric oxide levels. Artif Organs 2000; 24: 387-390.

25. Heering P, Morgera S, Schmitz EJ, et al. Cytokine removal and cardiovascular hemodynamics in septic patients with continuous venovenous hemofiltration. Intensive Care Med 1997; 23: 288-296.

26. Millar AB, Armstrong L, van der Linden J, et al. Cytokine production and hemofiltration in children undergoing cardiopulmonary bypass. Ann Thorac Surg 1993; 56: 1499-1502.

Received 2 October 2002

Accepted 2 December 2002 


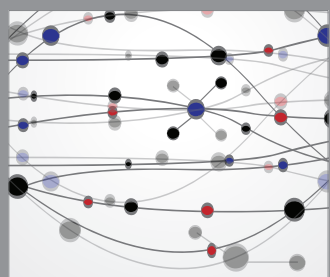

The Scientific World Journal
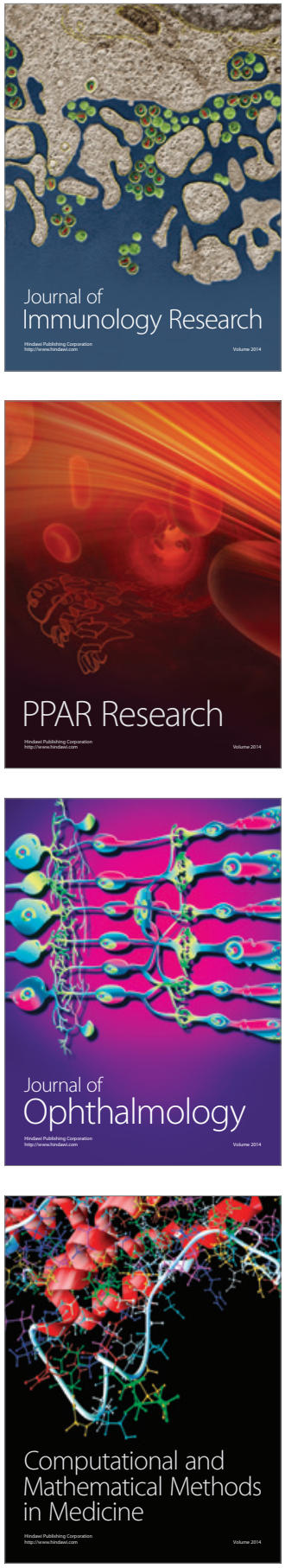

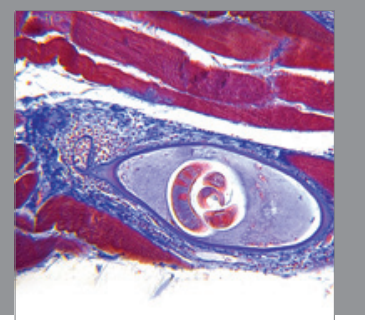

Gastroenterology

Research and Practice
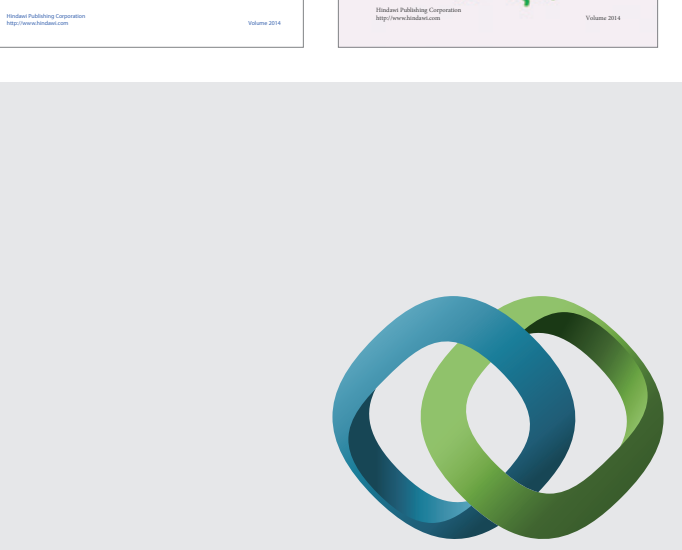

\section{Hindawi}

Submit your manuscripts at

http://www.hindawi.com
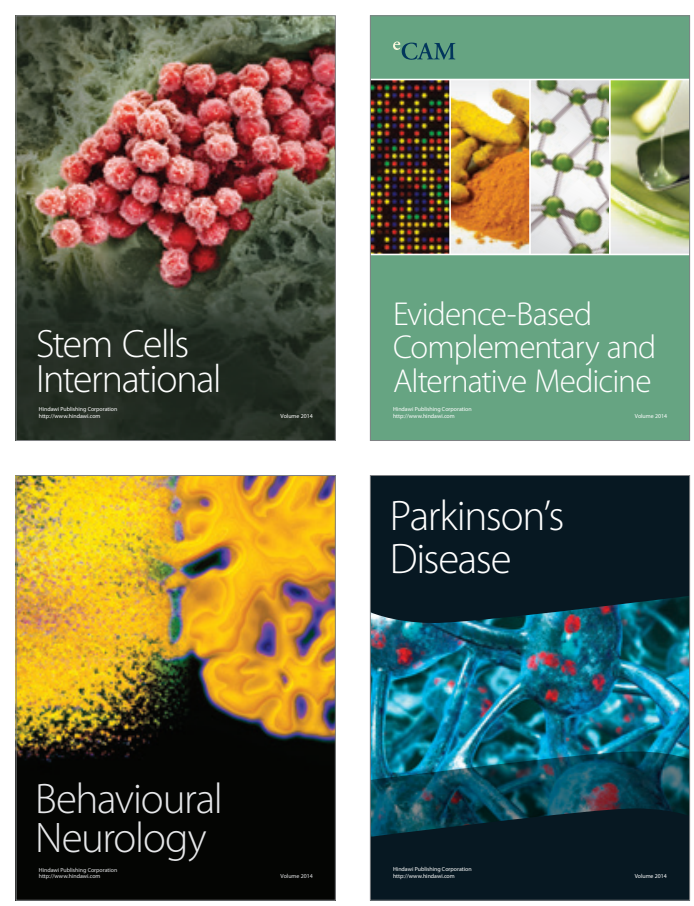

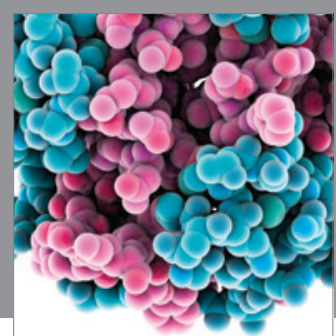

Journal of
Diabetes Research

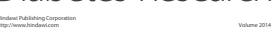

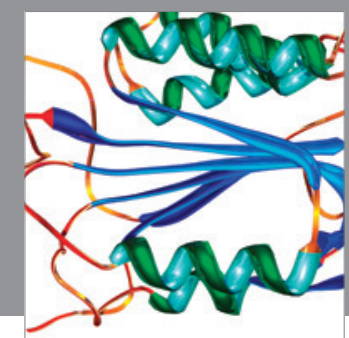

Disease Markers
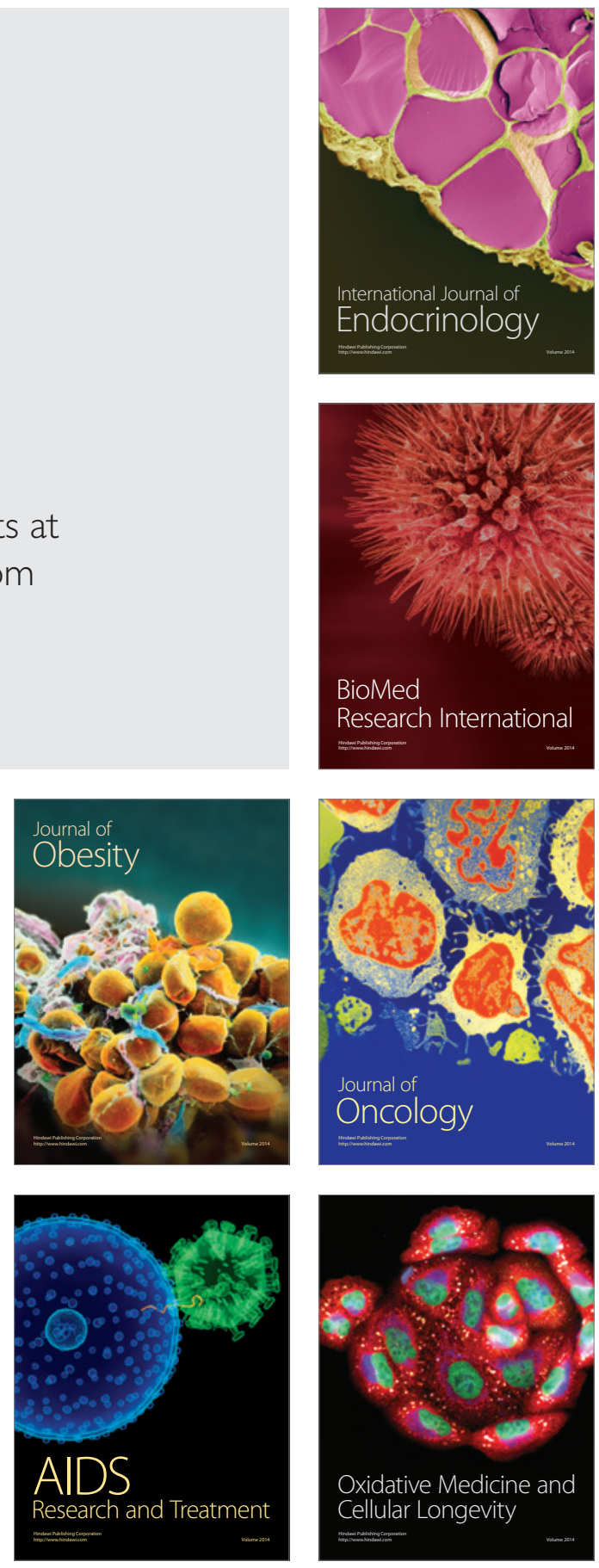